\title{
Assessment of Artificial Swtching Barriers in Carbonated Soft Drink Industry in Nigeria
}

\author{
Kola Olorunleke, Ph.D \\ Business Administration Department, AdekunleAjasin University, Akungba-Akoko, Ondo State, Nigeria.
}

\begin{abstract}
This paper investigated the relationship between the practices of imposing barriers on switching, the freedom of choice and ethical issues arising there from, in carbonated soft drink industry in Nigeria. Using convenience sampling, a sample of 200 respondents (88 females and 112 male) was drawn from hotels, restaurants, and other exclusive outlets. We employed a five Liket-scale response ranging from strongly disagree, disagree, neutral, agreed to strongly, agreed. The study found that some consumers that is loyal to competing products may also decide not to patronize the outlets where barriers to choice are imposed thereby leading to loss of purchase. Also, where formidable and practicable, instituting barriers may provide competitive instrument provided loss of sale can be minimized but it should not be encouraged so that emerging products and competition can have a level playground for competition.
\end{abstract}

\section{Introduction}

Switching behavior includes making decision to switch from product or organisation which customer currently patronize with another product or organisation and also predicting factors that influence this decision Most of the writers on switching discussed consumer switching behavior in service industry. for example M. Saklish, K.S. Kumar \&Ujor Naveen and V. Jeevaneethon (2011), sukekyu Lee, Fred Zufyden and XaxerDareze (2002), Sharaffi Value, ResonlAginiMehr, Seyyed Mohammed and Tabalabael (2013), OyeniyiOmotayo and AbiodunAbolajiJoachim (2008), just to mention a few. . It is important to note that customer also switch in consumer goods sector and it is easier and more pronounced.

Switching behavior is a consumer behavior where the behavior of the consumers differs based on the satisfactory level of the consumer with the company or the product. Switching behavior can be defined as the process of patronisingone service or product and then switching to another service or product, due to dissatisfaction or any other problem. If a consumer is loyal to a particular brand, if the brand does not satisfy $\mathrm{him} / \mathrm{her}$ needs, the consumer switch to competitor brand. There are many factors which affect the consumers in switching from one user to another. This may include the cost of switching(porter 1980, Jackson 1985, Ping 1993, among others), past behaviors, (for example Liljander and Stradvik1995), interpersonal relationship (jones et al 2002) and many other factors.

However, there is a situation where companies make it difficult for consumers to switch or have a freedom to switch from one product or services to another particularly in Nigeria.This is what we refered to as organizationally created switching barrier or artificial switching barriers. Companies tend to use this to prevent consumers from swicting to another competitive product or service. This practice is done through the use of distribution channels or what we call collaborators especially it is more noticeable in soft drink industry in Nigeria. The channels used include hotels, recreation centers,eatery and so on.

This paper intends to appraise the moral and hence ethical issues involved in this artificial practices and the consumer perception of this practices so as to bring out the implications to public and corporate policy makers.

\section{Literature Review}

Switching or change happens when the customers cuts their business relationships with the organization (Stwart, 1994, Hirshman, 1970). Buth (1998) argued that switching happens when a customer decides not to buy service(s) whether the whole or specific services. In banking industry, switching customers change their bank (Gralend, 2002). Switching is a natural intention of customers to cut business relationships with a firm permanently or for a specific period of time (Chandra and Krishna, 2006). To put it a simple way, switching points out the customers who decides to replace a service provider with its competitors. Thus, switching is divided into general and trivial switching. The later means that the customer supplies parts of previous or new services from new providers; while in the former; the customer completely cuts the business relationships and replaces the service provider with new ones. Complete switching is easily detectable, while it is not the same in the case of trivial switching. Trivial switching may turn into complete switching in time. In Customers switching, companies might be losing customer for different reasons. To put it more accurately, switched customer is the one that is about to stop using the services and switch to services provided by the rivals 
(Heden, 2005). Two general groups of switching can be noted; switching by will and mandatory switching (Henden, 2005). The former happens when the organization stops delivering a service for, among many, misuse of the services or unpaid bills. On the other hand, switching by will happens when the customer deliberately decides to stop using the services and switches to the rivals. The causes of such behavior are technological changes, economic concerns, qualitative concerns, type and availability of the services, and even bad experiences with the employees (Kim and Ion, 2004). Regarding business intelligence, managerial measures to deal with switching customers encompasses two main sets of analytical models; 1 - spotting groups of customer who may tend to switch; 2- finding the most effective reaction in such cases even if it remains silence. Barz and Vendonpol(cited in VahidSharafi, RasonelAzimiMehr, and Seyyed Mohamed TabatabaelMehriz(2007))introduced two attitudes that influence customer switching management; proactive approach and reactive approach. In reactive approach, the company tries to keep the customer in the company only when the customer requests termination of the business relationship. On the other hand, under the proactive approach, the company tries to avoid this by spotting groups of customers who may switch and persuade them by offering incentives and privileges. Management experiences show that the proactive approaches are more effective that reactive ones, while they are more economic (part of the costs of losing customers occurs in the form of social profits that is acquired by the rivals and negative words of mouth advertisement). Furthermore, proactive approach needs high accuracy coefficient to avoid wasting resources for the customer who are not potential switching customers. Implementation of data-mining processes in large businesses can lead to development of a system that response before the customer decides to switch. Such systems provides a framework to enforce proactive control-preferred from of managerial control (Gladi, 2009).

\section{Switching Behaviour}

Switching behavior includes making decision to switch the 0rganisation, which currently provides product or services, with another organisation and also predicting factors that influence this decision. Taylor (2002) showed that customers who possess positive attitudes to change service providers have more tendencies to switch. When stringent behavioural controls are in place, i.e. cost of switching is low. Among such costs are habit braking costs, mental threats, and/or cognitive load. Furthermore, perceived behavioural control is strongly related to switching intention. Mental norms can be also be effective as customers with positive attitudes tend to neglect poor services in some cases. In addition, they showed that attitude towards switching is the strongest factor in switching. A notable point is that intention may only predict the customer's attempts to show a specific behavior; still a mere intention does not mean that it leads to an actual behavior. As a general rule, when people have stringent control over showing specific behaviors (i.e. perceived behvaioural control), intentions and purposes can be predicted with high accuracy. Studies have also revealed that past behavior can be a reliable predictor of future behavior. This hints that it is not easy to find a proper measure e for future behaviors, while the best measure we have is the past behavior. Perceiving why people switch service providers through recognizing the factors that influence their decisions in this regard leads us to define eight factors in switching behaviour including pricing, lack of contingency, inefficient services, inefficient service provision, responses and reactions by colleagues to inefficient services, advantages of the competitors, moral concerns and mandatory switching.

The concept of participation refers to relationship between an individual's perception of object based on intrinsic needs, values and interests; it may also refer to the customers perception of advertisement, type of product or decision to make a purchase, higher participation to solve problem, active search, and using available information to achieve most reasonable decision. Low participation rates hints that the customer does not recognize gravity of consequences of making a specific purchase and does not care if there are other alternatives (Engle, 1986). Thus, the question is if participation has any effect on switching intention and behvaiours. Studies conducted in banks have shown that participation has to do with the bank customer's engagement in choosing a bank; that is, the customer thinks that it is wise to choose a specific bank.

The factors that influence the customer to keep or stop using a service are function of switching motivations. Satisfactory service lead to keepusing and unsatisfactory services lead to stop using a service. Still, not all factors in leaving have to do with switching (Colgate, 2007). Among the factors that motivate customers to stay with a service provider are costs/problems of switching so that the less the costs/problems, the stronger the intentions to switch.

\section{Switching Barriers}

Jones et al (2000) defined the switching barriers as three barriers: interpersonal relationships, perceived switching costs, and attractiveness of alternative. Interpersonal relationships refer to the existence and strength of the personal relationship between a customer and a service employee. Perceived switching costs are the perceived cost of time, money, and effort from customers associated with changing service providers. Patterson and Smith (2003) explored cross-culture service to categorize six switching barriers: search costs, loss of social 
bonds, set-up service costs, functional risk, attractiveness of alternatives, and loss of special treatment benefits. Patterson (2004) proposed psychological costs, economic costs, and set-up costs. Balabanis et al (2006) viewed seven switching barriers for an online business: familiarity, convenience, parity, economic, speed, unawareness, and emotional. Kim et al (2004) and Chang and Chen (2007) adopted the measurements of switching barriers from Jones et al (2000) to apply them to mobile telecommunications and airlines industries.

White and Yanamandram (2007) referred to five switching costs: uncertainty costs, pre-switching costs, set-up costs, post-switching costs, and benefit/loss costs. Uncertainty costs is the psychological uncertainty for an untested service provider (Guiltinan, 1989). Pre-switching costs are the time and effort of search and evaluation costs, which are the same in Jones et al (2000). Set-up costs are the time and effort for setting up the new service process associated with a new provider (Guiltnan, 1989). Post-switching refers to acquiring and adapting to the new procedures from Jones et al. (2000). Benefit/loss costs are the loss of benefit which is offered from an incumbent when the customers switch to the new provider (Guiltnan, 1989; Turnball and Wilson, 1989).

A body of research has also examined two or more factors that seem to have influenced a customer's decision to remain with a service provider. Studies have investigated service quality, switching costs and loyalty (Ruyteret. Al 1998), and availability and attractiveness of alternatives and switching costs (Sharma and Patterson, 2000; Grace and O'Cass, 2003). None of the studies focused on the effect of the barrier(s) amongst dissatisfy customers.

\section{Switching Cost}

Switching costs are conceptualized as the customer's perception of the magnitude of the additional costs required to terminate the current relationship, and secure an alternative (Porter, 1980; Jackson, 1985; Ping, 1993). These perceived penalties for disloyalty deter customers from switching to a competing firm. Switching costs include not only those that can be measured in monetary terms but also the psychological effect of becoming a customer of a new firm, and the time and effort involved in buying new product (Dick and Basu, 1994; Kim et. al. 2003; Klemperer, 1995; Sengupta et. al. 1997). The literature also discusses switching costs in the context of industrial buyer-seller relationship; with B2B marketing theorists offering a two-part (Speakman and Strauss, 1986; Nielson, 1996) or a three-part typology (Jackson, 1985).

Gronhaug and Gilly (1991) argue that a dissatisfied customer may remain loyal because of high switching costs. It has been argued that the costs of switching providers tend to be higher for services than for goods (Gremler and Brown, 1996). Switching costs are high for services that are intrinsically difficult to evaluate, or for which there is only a limited number of suppliers (Brown and Swartz, 1989; Patterson and Johnson, 1993). Literature in the areas of industrial marketing and distribution channels also suggest that a relationship may continue to exist due to the buyer's perceptions of the high switching cost (Porter, 1980; Ping 1994) even if the relationship is not a satisfactory one. In this situation, the customer does not feel any strong links with the service provider, but repeats the same buying behavior in order to reduce the perceived risk linked to a bad choice (Bozzo, 2002). Perceived risk implies customers experience pre-purcahse uncertainty as to the type and degree of expected loss resulting from the purchase and use of a product or service (Cox, 1967). Since services are intangible and heterogeneous, customers will perceive risk increases, the likelihood of loyalty to one brand increases (Javalgi and Moberg, 1997).

A number of studies have empirically tested switching costs as a main determinant of customer loyalty in consumer markets (Gremler, 1995; Ruyter et. al., 1998; Burnham et. al, 2003; Beerli et. al. 2004; Caruana 2004) as well as in a B2B service context (Lam et. al. 2004). Further, the main effect of some switching barriers on customer retention has been empirically validated in consumer settings (Lee et. al. 2001) as well as the effect of barriers (such as interpersonal relationships, switching costs, attractiveness of alternatives) evident regarding the propensity to stay with the service providers (Jones et. al., 2000; Patterson and Smith, 2003). Heide and Weiss (1995) found that switching costs acted as the main determinant of behavioral loyalty, and not as a mediator in a B2B setting.

Richard Lee, Jamie Murphy, University of Western Australia (2005), in their study investigates determinants that cause mobile phone Customers to transit from being loyal to switching. It concluded that there are different factors which affects the customers to switch from loyalty to switching intentions such as price, technical service quality, Functional service quality, switching costs, etc. but, the rating was given that price is the most important factor which affects the customers to switch loyalties to another provider.

Mohammed Sohel Islam (2008), in his study examined the relationship between switching cost, corporate image, trust and customer loyalty. The research finds that although all the independent variables, switching cost, corporate image, and trust have certain degree of relationship with the dependent variable, customer loyalty, only trust has the strongest relationship with customer loyalty.

ConorTwomey (2008), Department of Statistics, University College Cork, Ireland, they try to identify hysteresis in the switching patterns of customers in the Irish mobile phone industry. MitjaPirc, 
UniversitatPompeuFabra (2006), Spain, the Mobile telecommunications service sector, in spite of providing high service quality and striving for customer satisfaction, is characterized by dynamic customer services and mobile phone, he provides the explanation on the factors of customer switching. It is found that the mobile services usage effect on switching intentions is curvilinear (positive linear and negative quadratic) and that only the budgetary constraint regarding the service matters and not the one related to the mobile phone. Past mobile service providers switching experience also contributes to the intention to switch. Mobile phone ego involvement has positive impact on Customer retention; however, purchase involvement (both mobile phone and mobile services) increases customer risk.

Oyeniyi, Omotay and AbiodunAbolaji Joachim (2008), He attempts to find the relationship between Customer services on Customer retention in telecommunication industry in Nigeria. If retention is not managed, Customer's loyalty may be lost. He examines the potential constructs in Customer retention by investigating the chain of effects of retention from Customer service, satisfaction, value and behavioral intention. The hypotheses are supported except that a higher level of Customer satisfaction does not lead to Customer loyalty. Customer satisfaction does not necessarily lead to customer's loyalty. It is assumed that when the customer is satisfied, then loyalty towards the telecom company is strengthened. Their results, further show that the respondents in their study have a positive impression towards their telecom company's ability to meet their changing needs.

\section{Interpersonal Relationships}

Interpersonal relationships refer to the strength of personal bonds that develop between customers and their service employees (Turnbull and Wilson, 1989; Berry and Parasuranam, 1991). The interpersonal relationship built through recurrent interactions between a service provider and a customer can strengthen the bond between them and lead to a long-term relationship (Kim et. al., 2004). Interpersonal relationships are especially important in services given the high degree of personal interaction, the intangible nature of the service, the heterogeneity of service outcomes, and the prominent role customers play in service production (Czepiel, 1990). Liljander and Strandvik (1995) describe a "knowledge bond" as a type of bond that serves as an exit barrier for the customer who continues to deal with a service provider with whom they are dissatisfied because they have confided in them for so long. Joneet. al. (2000) discovered that, in situations of low customer satisfaction, strong interpersonal relationships positively influence the extent to which customers intend to repurchase. Gwinneret. al. (1998) argue that even if a customer perceives the core services attributes as being less than optimal, they may remain in a relationship if they are receiving important relational benefits. In this regards, researchers (for example, Frenzen and Davis, 1990; Dick and Basu, 1994) contend that social benefits mitigate the influence of satisfaction with the core service by encouraging customers to remain with their service provider even in situations where core-service satisfaction is less than complete in consumer markets. Social benefits have been presumed to include feelings of familiarity, personal recognition, friendship, rapport, and social rapport (Barnes, 1994).

While some scholars have included interpersonal relationships as a dimension of switching costs (Jone et. al. 2002; Burnham et. al. 2003; Patterson and Smith, 2003), others have treated them as two separate constructs (Ping, 1993; Wathne et. al., 2001). While both interpersonal relationship and switching costs derive from previous investments in the supplier/service provider relationships derive from an individual's investment in social capital (Coleman, 1990), switching costs arise from organizational level investments in transactionspecific assets (Williamson, 1985). Thus, each dimension exists at a different level, that is, interpersonal and inter-organizational, respectively (Wathne et. al. 2001). In Wilson's (1995) terminology, these two factors are examples of social and structural bonds, respectively. Hence, interpersonal relationships and switching costs are treated in this study as two separate determinants.

\section{The negative and positive switching barriers}

Customers' motivation to maintain relationship with their service provider can have two origins: either they have to continue a relationship because of constraints or they want to stay in a relationship because of dedication. There is a great difference between these two reasons for continuing the relationship (Julander\&Soderlund 2003).

In the first case, the relationship between customers and their service provider is a "constraint-based relationship" (Bendapudi\& Berry 1997), which can be imposed on the customers in a formal or informal way. The relationship is maintained according to the customer's evaluation of the switching alternatives. This evaluation compares the exit costs and the difference between the profits hoped-for at the competing providers and the profit from the current situation. If this evaluation is positive, the customer is in a position of weak economic dependence that facilitates the change. In the opposite case, the customer is in a situation of dependence and is more or less forced to maintain the relationship. Its decision to continue or end the current 
relationship with his service provider is determined by the degree of perceived dependence; the more significant this dependence, the more the customer is obliged to stay.

In the second case, consisting of a "dedication-based relationship" the continuity of the relationship is actively desired by customers (Stanley \&Markman 1992). Customers maintain relationship because they wish it, without being limited by constraints in their choice. This second category supposes the existence of an emotional link between customers and their service provider (Bendapudi\& Berry 1997). Customers are less receptive to the competing offers and less inclined to search for alternatives. The availability of attractive alternatives on the market (Henning-Thurau\& al. 2000) has no influence on this type of relationship.

Contrary to the classification of Julander\&Soderlund (2003), the risk perception barriers are in the negative switching barrier (NSB) category. This type of barrier can cause a feeling of detention in the relationship and does not allow the development of positive attitudes. In the mobile telephony sector, because of the market oligopoly structure, the lack of attractive alternatives (Vazquez-Carrasco \&Foxall 2006) increases the risk of switching. Consequently, the risk perception barriers do not have a positive influence on the customer's attitude to his current service provider.

In the positive switching barrier (PSB) category we can find the economic performance barriers, the functioning performance barriers and the relational performance barriers. These barriers have the following origins: rewards customer loyalty with special offers, (e.g, gifts, discounts); ease of functioning (e.g. satisfaction of the specific needs); interpersonal links (e.g. familiarity, attention, friendship or affinity). Their common point is that they contribute to increase the customer's positive attitudes towards their service provider and strengthen the relationship. They make an active contribution to developing the customer's commitment (Julander\&Soderlund 2003).

In summary, Most of the studies mentioned in literature and host of others concentrated their work on service industry. This paper tends to look at switching barriers in product/goods industry using carbonated soft drinks industry. This paper also attempts to work on organizationally or artificially created switching barriers as against switching barriers caused by customers willingness to switch. kovesi, klan and phillipe RobertsDesmondround(2010).

\section{Artificial Switching Barrier by Cocacola Company Plc \\ III. Research Methodology}

In an interview with the sales personnel of Coca-cola Bottling Company Plc, one of the major ways of fighting competition is through building a barrier that will make it impossible for customer or consumer to switch to other competitor's product. Some of the practices includes

1. Building/Renovating restaurants for customers and insisting of selling only Cocacola (Food vendor sector)

2. Providing utilities like TV, Bedspread, Freezer and so on to major hotels and insisting on exclusively selling cocacola product (hotel and recreation sector)

3. The owners and its entire household

4. Special additional commission or discount to the exclusive outlets

5. Special depots in schools and other recreational areas where anybody that attends will have to market cocacola products.

Two issues arises from this practice

1. The freedom of choice

2. The ethical issues arising from this practice

On these issues, we sought the opinion of customer patronizing the exclusive sectors mentioned above. The fact above indicated the patronage by customer is not because of loyalty or commitment but customers have no choice

\section{Hypothesis}

Twohypotheses were developed from the issues mentioned above.

$\mathrm{H}_{1}$ The exclusive practices of cocacola do not force relationship on the customers

$\mathrm{H}_{2}$ The exclusive practices of cocacola do not have relationship with the fairness to customer

Considering of the type of research and the large population size and the necessity to use the responses of the participant, the best way for data collection is through questionnaire. The research also used interview to get information about the artificial barrier practices in cocacola bottling plant in IlorinSamples of customers were selected from an near infinite population since consumers of cocacola are spread all over the regions and it is difficult to get their numbers. A sample of 200 respondents was chosen using the convenience sampling. The researchers visited the hotels, restaurants, and other exclusive outlets to distribute questionnaire to the consumers met at the place as at that time. A five Liket-scale response ranging from strongly disagree, disagree, 
neutral, agreed to strongly, agreed was used. (See Appendix for a profile of sample respondents is prevented in table below)

\section{Results And Interpretations}

Since the questionnaires are administered personally, the entire 200 questionnaire was returned fully filled. A t-statistic was used to test the hypothesis

\section{Test of hypotheses}

Hypothesis one

\begin{tabular}{|l|l|l|l|l|}
\hline Standard coefficient & t.value & Independent variable & Dependent variable & Result \\
\hline $72 \%$ & 86.9 & Exclusive practices & Freedom of choice & Ho not supported \\
\hline
\end{tabular}

As hinted in the table above, standard coefficient between exclusive practices and freedom of choice is $72 \%$. That calculated t- value $=8.69$ is greater than the table value of 1.96 . For this reason, Ho is rejected and $\mathrm{H} 1$ is supported. Thus, the exclusive practices of cocacola affect the freedom of choice of the respondents.

\section{Hypothesis two}

\begin{tabular}{|l|l|l|l|l|}
\hline Standard coefficient & t-.value & Independent variable & $\begin{array}{l}\text { Dependent } \\
\text { variable }\end{array}$ & Result \\
\hline $84 \%$ & 26.10 & Exclusive practises & $\begin{array}{l}\text { Fairness to } \\
\text { customer }\end{array}$ & $\begin{array}{l}\text { Ho not } \\
\text { supported }\end{array}$ \\
\hline
\end{tabular}

As listed in the table above, standard coefficient between exclusive practices and fairness to customer is 0.84 with $t$-value of 26.10. sincet.value calculated is more than $t$-value $=1.96$, that is $26.10>1.96$, we reject the null hypothesis and accept the alternative hypothesis. Thus, the exclusive practices of cocacola is not fair to the consumers.

\section{Conclusions And Recommendations}

The results regarding hypothesis, that is, the relationship between the practices of imposing barriers on switching, the freedom of choice and ethical issues arising there from, all show that customers do not like to loose their freedom of choice. When askbenefit temporarily but in the long run, they will have the problem of loss of freedom of choice. Some consumers loyal to competing products may also decide not to patronize the outlets where barriers to choice are imposed thereby leading to loss of purchase. Where formidable and practicable, instituting barriers may provide competitive instrument once loss of sale can be minimized but it should not be encouraged so that emerging products and competition can have a level playground for competition.

\section{References}

[1]. Balabaws et al, Reynolds N and Simiutiras A. (2006) "Bases of E.store loyalty: perceived switching Barriers and satisfaction. "Journal of Business research (39:2), pp 214-224.

[2]. Barnes, J.G. (1994). “ The issue of establishing relationships with customers in service companies: when are relations feasible and what form should they take? Presented at the third annual frontiers in service Vanderbut University, Nashville, TN, October 6-8.

[3]. Beerli, A, Martin, J.D and Quintana, A. (2004)." A model of customer loyalty in the retail banking market”. European Journal of marketing. Vol.38, No.1/2, pp 253-275.

[4]. Bendapudi. N: and Berry L.L (1997). Customer's motivations for maintaining relationships with service providers, Journal of Retailing.Vol.71, No.3.pp 223-47.

[5]. Berry, L. and Parasunaman, A. (1991). Marketing service: competing through quality, New York, The Free Press.

[6]. Boo, C. (2002). Risk taking and information handling in consumer behavior, Graduate school of Business Administration, Harvard.

[7]. Boote, J. (1998). Towards a comprehensive taxonomy and models of consumer complaining behavior.Journal of consumer satisfaction, Dissatisfaction and complaining Behavior, 11, 141-149.

[8]. Browns, S.W. and Swart, T.A. (1989) “ A gap analysis of professional service quality” Journal of marketing, Vol.53, No.2, pp.427.

[9]. Burnham et al (2003) "Consumer switching cost: A typology antecedents, and consequences," Journal of the Academy of marketing science, Vol.31, No.2, pp 109-126.

[10]. Calgate M. \& Hedge R (2001). An investigation into the switching process in retail banking service: The international Journal of Bank Marketing, 19 (4/5), 201-213.

[11]. Carvana, A. (2004). "The impact of switching costs on customer loyalty: A study among corporate customers of mobile telephone". Journal of targeting, measurement and analysis for marketing. Vol.12, No.3, pp 256-268.

[12]. Chanclar M. Laha, A \& Krishna P, (2006) modeling churn behavior of Bank customers using predictive data mining techniques. In National conference on soft computing techniques for engineering publications, March 24-2.

[13]. Chang, H.H, and Chen, S.W, (2008) "The impact of customer interface Quality, satisfaction and switching cost on E.loyalty: internet Experience as a moderator, "computers in Human Behavior (24:6), pp 2927-2944

[14]. Coleman (1990).Foundation of social theory. Cambridge M.A: Harvard University Press.

[15]. Czepiel.J. (1990), "Service encounters and service relationship implication f6ro research" Journal of Business Research, Vol. 20, No 1, pp. 13-21.

[16]. Dick, A.S. and Basu, K. (1994), "customer loyalty: Towards an integrated conceptual framework," Journal of the Academy of marketing science. Vol.22 (spring), pp.99-113.

[17]. Engel et all, Blackwell, R.D \&Miniard, P.W (1995). Consumer behavior $\left(8 \mathrm{t}^{\text {hed }}\right)$ Fort Worth: The Dryclen Press. 
[18]. Frenzen, J.K and Davis, H.L (1990) "Purchasing behavior in embeded markets.Journal of consumer Research. Vol.17, June, pp. 111.

[19]. Garland, R (2002) "Estimating customer refection in personal retail Banking" The International Journal of Banking Marketing. 20(7), 317-325.

[20]. Grace, D. and O Cass, A. (2003), "child care service: An exploratory study of choice, switching and search behavior," European Journal of marketing. Vol. 37, No. 1/2, pp. 101-32.

[21]. Gremler, D.D and Brown, S.W (1996).“ service loyalty, its nature importance and implications. In Edvardsson B, Brown, S.W Johston, R. and Scheuing, E. (Eds) Quis V: Advancing service quality: A global perspective. ISQA, New York, pp. $171-81$.

[22]. Gremler, D.D. (1995), "The impact of satisfaction, switching costs and interpersonal bonds on service loyalty" Phd Dissertation Arizona state University.

[23]. Gronhaug, K. and Gilly, M. (1991)" A transaction cost approach to consumer classification and complaint actions: Journal of economic psychology. Vol. 12, pp. 165-83.

[24]. Guitinan, J.P. (1989). A classification of switching costs with implication for relationship marketing. AMA winter Education Conference: Marketing Theory and Practice. 216-220

[25]. Gwinner et al. (1991) "Relational benefits in services industries. The customer's perspective," Journal of the Academy of marketing science. Vol. 26, No.2, pp. 101-14.

[26]. Heide, J.B. and Weiss, A.M (1995), “Vendor consideration and switching behavior for buyers in high-technology markets, “Journal of marketing. Vol.59, No.3, pp 30-43.

[27]. Hirschman, A.O (1970), Exit, voice and loyalty, Harvard university Press, Journal of social issues \& Humanities. Vol. 3, issue 1, January 2005 2345-2633

[28]. Jackson R.W, Neideu L.A and Iunsford D.A. (1995) “ An empirical investigation of the differences in goods and services s perceived by organizational buyers industrial marketing management, Vol. 24, No 2, pp. 99-108

[29]. Jackson, BB. (1985), Winning and keeping industrial customers: The dynamic of customer relationships, Lexington Books, Lexington.

[30]. Javalji, R.G. and Moberg, C.R. (1997). "Service loyalty: implications for service providers" Journal of services marketing. Vol. 11, No 3, pp. 165-79.

[31]. Jones et al (2007) Mothersbaugh, D.L and Beathy, S.E "Switching Barriers and Repurchase intention in service" Journal of Retailing (76:2) 2000, pp 259-274.

[32]. Julander C.L and Soderlund, M. (2003), "Effects of switching barriers on satisfaction repurchase intention and attitudinal loyalty." SSE/EFI working paper series in Business Administration, No: 2003, Stockholm, 2-22.

[33]. Kim et al (2003) Estimating switching costs: The case of banking” Journal of Financial Intermediation, Vol.12, No.1, pp 25-56.

[34]. Kim, et al, Yoon, C.H (2004).Determinants of subscriber churn and customer loyalty in the Korean mobile Telephone market. Telecommunications policy, $28(9)$, pp: 751-765.

[35]. Kim, H.S, Yoon, C.H (2004). Determination of subscribe churn and customer loyalty in the Korean mobile Telephone market. Telecommunications policy. 28(9), pp 751-765.

[36]. Klemperer, P. (1995), "competition when consumes have switching costs: an over view with applications to industrial organization, macro-economic and international trade", Review of Economic studies, Vol.12, pp. 515-394.

[37]. Lam, et al. (2004), "customer value, satisfaction, loyalty and switching costs: An illustration from a business-to-business service context", Journal of the Academy of marketing science. Vol.32, No.3, pp. 293-311.

[38]. Lee et al (2001), "The impact of switching costs on the consumer satisfaction-loyalty link: Mobile phone service in France.” Journal of service marketing. Vol.15, No.1, pp 35-48.

[39]. Liljander, V. and Strandvik, T. (1995), “ The nature of customer relationships in service in swartz, T.A, Bowen, D.E. and Brown S.W. (Eds). Advances in service marketing and management.Vol. 4, pp 141-67.

[40]. M.sathish, K.Santhosh Kumar, K.J. Naueen, V.Jeevananthan (2011). A study on consumer switching behavior in cellular service provider: A study with reference to channai, for East Journal of psychology and business, vol. 2 No 2, February.

[41]. Oyeniyi, Omotayo and AbiodunAbolajiJoachchim (2008) customer service in the retention of mobile phone users in Nigeria, African Journal of Business Management.Vol.2 (2), pp 026-031, Feburary.

[42]. Patterson (2004), “ A contingency model of behavioral intention in a services context” European Journal of marketing, Vol. 38, No.9/10, pp. 1304-1315.

[43]. Patterson, P.G and Johnson, L.W. (1993).“ Disconfirmation of expectations and the gap model of service quality: an integrated paradigm". Journal of consumer satisfaction.Dissatisfaction and complaining behavior, Vol.6, pp 90-9.

[44]. Patterson, P.G and Smith, T. (2003) "A cross cultural study of switching barriers and propensity to stay with service providers" Journal of Retailing, Vol. 79, pp. 107-120

[45]. Ping, R.A ( 1993), "The effects of satisfaction and structural constraints on retailer existing voice, loyalty, opportunism, and neglect", Journal of retailing, Vol. 69, No 3, pp. 320-353.

[46]. Ping, R.A. (1994). " Does satisfaction moderate the association between alternative attractiveness and exist intention in a marketing channel. Journal of the Academy of marketing science, Vol. 22 Fall, pp. 364-71.

[47]. Porter, M.E (1980), competitive strategy: techniques for analyzing industries and competitors, free press, New York.

[48]. Richard Lee Murphy, Jamie (2005), "From loyalty to switching: Exploring determinants in the Transition," ANZMAC 2005, Perth, Australia, December.

[49]. Ruyter, Clek, Bloemer J, M. and Wetzels, M.G. (1998) "on the relationship between perceived service quality, service loyalty and switching costs" International Journal of Service Industry Management, Vol.9, No. 5, pp. 436-453.

[50]. Sengupta et al. (1997) "switching costs in key account relationships". The Journal of personal selling and sale management. Vol.17, No 4, pp. 9-16.

[51]. Sharma and Patterson (2000). "switching cost, alternative attractiveness and experience as moderators of relationship commitment in professional, consumer services". International Journal of services industry management, Vol. 11, No 5, pp. 470-490

[52]. Spekman, R.E and Strauess, (1986), “An exploratory investigation of a buyer's concern for factors affecting co-operative buyerseller relationships" in Backhaus, K. and Wilson, D.T. (Eds) industrial marketing, Springar-veslag Berlin, pp. 115-33.

[53]. Stanley S.M. and Markman, H.J (1992), “Assessing commitment in personal relationship.Journal of marriage and the family. 54, 3, $595-608$

[54]. Stewart, K. (1997). An exploration of customer exit in retail Banking International Journal of Bank marketing 16 (1), 6-14

[55]. Sukekyu Lee, fredzufryclen, and Xavier Dreze (2002). A Study of consumer switching Behavior Across internet portal websites.

[56]. Taylor, G.A, Roos, I \&Hamer, L. (2002) service separation anxiety: Understanding consumer reaction to involuntary switching retrivedjuly 1, 2009 from http://www.ihroos.fi/switching.htm 
[57]. Tung G, Kuo C and Kuo Y (2011).Australian Journal of Business and Management Research. Vol. 1, No 2, May.

[58]. Turnball, P.W, \& Wilson, D.T (1989). Developing and protecting profitable customer relationships: industries marketing management, 25(3), 233-8

[59]. VahidSharafi, RasoulAzimiMehr, and Seyyed Mohammed TabatabaeiMehrizi (2015) Journal of Social Issues \&Humanties, Volume 3, Issue 1, January.

[60]. Vazquez-Carrasco, R. and Foxall, G.R. (2006). "Positive vs Negative switching barriers: The influence of service consumers need for variety: Journal of consumer behavior, 5. 4, 367-379.

[61]. Wathne et al (2001) "Choice of supplier in embedded markets relationship and marketing program effects".Journal of marketing.Vol.65. April.Pp 54-66.

[62]. White, L. and Yanamenduam. V. (2004), "Why customers stay: reasons and consequences of inertia in financial services". Managing services Quality, Vol.14, No 2/3, pp 183-194

[63]. Williamson, O.E. (1985). The Economic Institutions of capitalism, New York: The Free Press.

[64]. Wilson, D.T. (1995). “An integrated model of buyer-seller relationship.”Journal of the Academy of marketing science.Vol.23, No.4, pp 335-45.

[65]. Yanamandram, V \& White, L. (2004). Switching barriers in business-to-business service: a qualitative study, International Journal of service Industry Management, 17 (2), 158-92.

\section{APPENDIX}

A profile of sample respondents is prevented in table below.

\begin{tabular}{|l|l|l|l|l|}
\hline variables & $\mathbf{N}$ & & \multicolumn{2}{|c|}{ Total respondents } \\
\hline & & & Frequency & $\begin{array}{l}\text { No. of respondents per option } \\
\%\end{array}$ \\
\hline Gender & Valid & Female & 88 & 44.0 \\
& & Male & 112 & 56.0 \\
& & Total & $\mathbf{2 0 0}$ & $\mathbf{1 0 0}$ \\
\hline Age & Valid & $18-30$ & 27 & 13.50 \\
& & $31-45$ & 42 & 21.00 \\
& & $46-50$ & 29 & 14.50 \\
& & $51-65$ & 55 & 27.57 \\
& & $66+$ & 47 & 23.5 \\
& & Total & $\mathbf{2 0 0}$ & $\mathbf{1 0 0}$ \\
\hline Education & Valid & Secondary Edu. & 19 & 9.5 \\
& & Diploma & 41 & 20.5 \\
& & Bachelor degree & 85 & 42.5 \\
& & Postgraduate degree & 55 & 27.5 \\
& & Total & $\mathbf{2 0 0}$ & $\mathbf{1 0 0}$ \\
\hline Occupation & Valid & Professional & 86 & 43.0 \\
& & Tradeperson & 53 & 26.5 \\
& & Others & 61 & 30.5 \\
& & Total & $\mathbf{2 0 0}$ & $\mathbf{1 0 0}$ \\
\hline & & Under N100,000 & 59 & 29.5 \\
& & N100,000-N199,000 & 92 & 46.0 \\
& & N200,000+ & 49 & 24.5 \\
& & Total & $\mathbf{2 0 0}$ & $\mathbf{1 0 0}$ \\
\hline & & &
\end{tabular}

